\title{
Influence of climatic factors on the growth and yield of sugar cane at Numan, Nigeria
}

\author{
N. L. Binbol ${ }^{1, *}$, A. A. Adebayo ${ }^{2}$, E. H. Kwon-Ndung ${ }^{3}$ \\ ${ }^{1}$ Department of Geography, Nasarawa State University, P.M.B 1022 Keffi, Nigeria \\ ${ }^{2}$ Department of Geography, Federal University of Technology, P.M.B 2076, Yola, Nigeria \\ ${ }^{3}$ Department of Biological Sciences, Nasarawa State University, P.M.B 1022 Keffi, Nigeria
}

\begin{abstract}
This study investigates the effect of climate on the growth and yield of sugar cane at the Savannah Sugar Company in Numan, Nigeria. Correlation and regression analysis were used to examine the relationship between sugar cane yield and climatic factors at different phenological stages of the crop. Results from the correlation analysis showed that several of the climatic factors studied significantly affect the growth and yield of sugar cane. Stepwise regression analysis identified 2 climate variables as the critical factors influencing crop yield: pan evaporation at the 'boom' (or 'grand growth') stage, and minimum temperature at germination stage. These 2 factors accounted for $>68 \%$ of the variation in the yield of sugar cane in the study area. The implications of the results are discussed with respect to sugar cane cultivation in the region.
\end{abstract}

KEY WORDS: Climate $\cdot$ Correlation and regression analysis $\cdot$ Nigeria $\cdot$ Sugar cane $\cdot$ Crop yield Resale or republication not permitted without written consent of the publisher

\section{INTRODUCTION}

Global climate change exerts a strong effect on local climate structure and patterns (Eriksen 2005), as does climate varibility (e.g. the El Niño events occurring over the last 3 decades of the 20th century caused floods, droughts and heat waves; O. Ojo unpubl.). On the other hand, conditions in the Sudan-Sahelian region of Nigeria have settled into a situation of relative drought persistence (O. Ojo unpubl.). Coupled with temperature and evaporation increases, this is likely to lower crop yields and thus significantly affect the sugar cane industry in Nigeria.

The economic importance of sugar cane has been stressed in the literature (Purseglove 1985, Korchar 1986). Nigeria spent a large sum of money on sugar cane importation (African Independent Television, 18:00 h news item, 8 September 2000, monitored in Abuja) until commercial cultivation of sugar cane started in 1950, and industrial production of refined sugar started in 1964 at the Nigeria Sugar Company
(NISUCO; the nation's principal producer of refined sugar) in Bacita. The Savannah Sugar Company Limited (SSCL), of Numan in Adamawa State (see Fig. 1) started commercial production in 1980. Other smaller mills were established at Lafiagi (Kwara State) in 1993, Sunti (Niger State) in 1994 and Sara (Jigawa State) in 1994.

While the SSCL has clearly benefited from advances in technology and improvement in the methods of sugar cane crop husbandry over the past $20 \mathrm{yr}$, sugar cane yield in region is still highly variable (see Table 1). With such agricultural and technological advances, climate remains the major factor influencing the variation in the crop yield. There is little published research on how climatic factors influence sugar cane production in Nigeria, despite the increasing importance of sugar cane production to the economy. This research is designed to examine the influence of climate on sugar cane growth and yield at the SSCL in Numan over a 20 yr period (1981-2000). 


\section{DATA AND METHODS}

The SSCL is located near Numan, Adamawa State, at $9^{\circ} 31^{\prime} \mathrm{N}$ and $11^{\circ} 49^{\prime} \mathrm{E}$ (Fig. 1) and the company sugar cane farm covers some 29000 ha. The climate of the area is characterized by 2 distinct seasons: wet (April to October) and dry (November to March). The mean annual rainfall is $905 \mathrm{~mm}$, the wettest months being
August and September. Temperatures are generally high throughout most of the year except from November to February when a local wind, the Harmattan (a NE wind originating in the Sahara desert), tends to reduce temperatures considerably. Between November and January the Harmattan pushes the Inter Tropical Discontinuity (ITD) to its most southerly latitude position of 2 to $5^{\circ} \mathrm{N}$. During this period most of

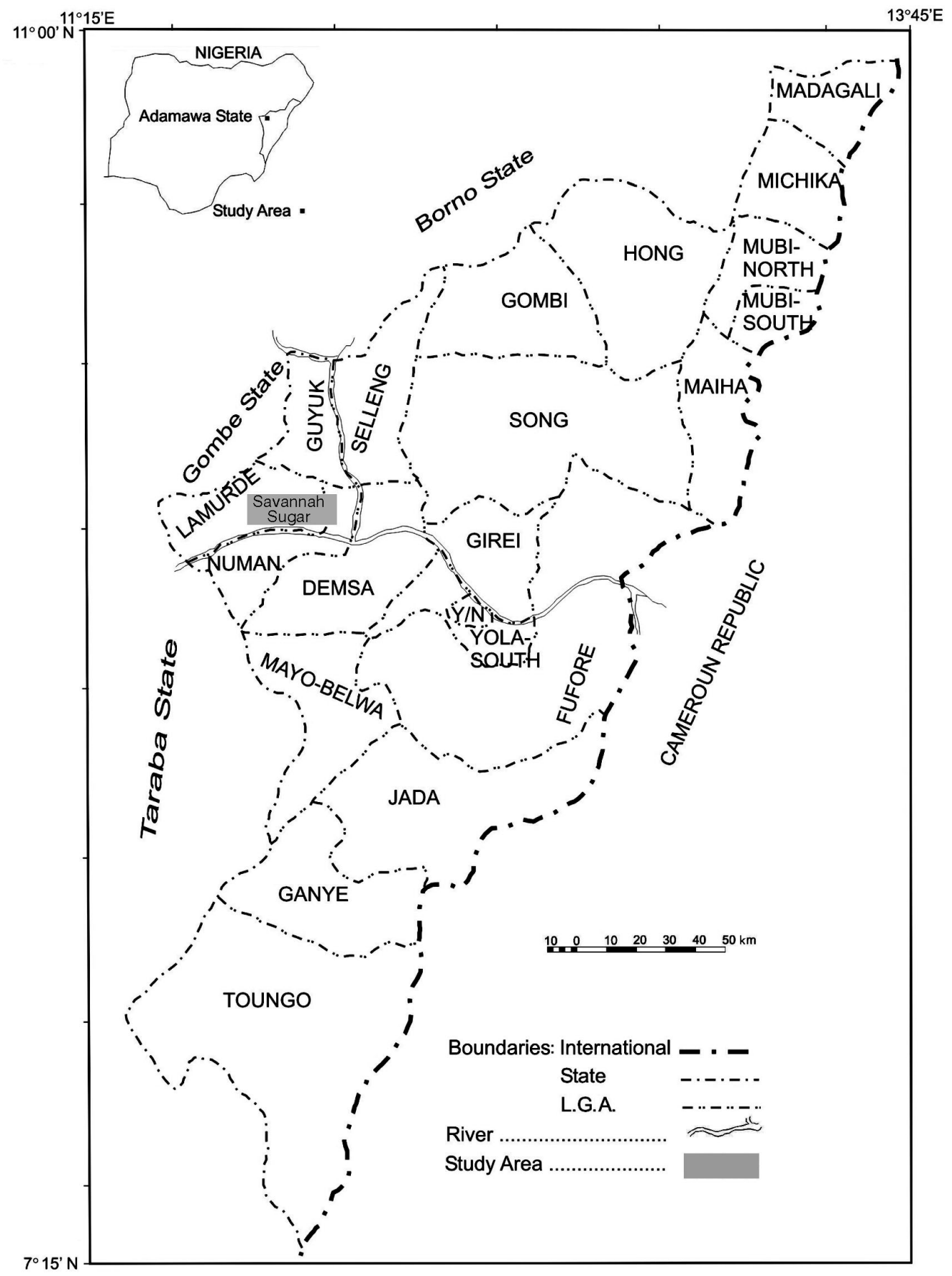

Fig. 1. Map of Adamawa State, Nigeria, showing the location of the Savannah Sugar Company study area 
Adamawa State is under the influence of a relatively stable dry continental air mass from the NE, and rainfall is very low (Adebayo 1999). The mean monthly temperature is $26.9^{\circ} \mathrm{C}$, with a range of ca. 18 to $40^{\circ} \mathrm{C}$ (Tmin and Tmax, respectively). Relative humidity ranges between a January low of $20-30 \%$ to a high of $80 \%$ in August/September. Topographically the area consists of alluvial plains along the Benue River and its major tributaries. The average elevation of this region ranges from 152 to $259 \mathrm{~m}$ above sea level (a.s.l.). The project site is covered mainly by vertisol soils, which are deep, fertile and suitable for sugar cane growing (Mirchaulum \& Eguda 1995).

Daily records of rainfall, relative humidity, maximum and minimum temperatures, evaporation, wind velocity and sunshine hours for the $20 \mathrm{yr}$ period (1981-2000) were collected from the meteorological station (No. 0911.35; 9 $34^{\prime} \mathrm{N}, 1^{\circ} 58^{\prime} \mathrm{E}$; $144 \mathrm{~m}$ a.s.l.) of the Agronomy Division of SSCL. Observations are made at both major and minor synoptic hours. The study made use of the 09:00 $\mathrm{h}$ entries for the entire $20 \mathrm{yr}$ period. Two years during the time period were dedicated to factory renovation, when cultivation and production did not take place. This period was not included in the analysis. Sugar cane yield data for the period under study were also collected from the Agronomy Division of SSCL. Sugar cane yield $\left(\mathrm{t} \mathrm{ha}^{-1}\right)$ and date of planting (1981-2000) are presented in Table 1.

Table 1. Yield of Sugar Cane at Savannah Sugar Company Limited (SSCL), Numan. -: company under renovation, no production. Source: SSCL (unpubl. data)

\begin{tabular}{|lcc|}
\hline Year & Yield $\left(\mathrm{t} \mathrm{ha}^{-1}\right)$ & $\begin{array}{c}\text { Date of planting } \\
(\mathrm{dd} / \mathrm{mm} / \mathrm{yr})\end{array}$ \\
\hline $1980 / 81$ & 88.64 & $30 / 3 / 1981$ \\
$1981 / 82$ & 77.45 & $27 / 3 / 1982$ \\
$1982 / 83$ & 56.13 & $14 / 4 / 1983$ \\
$1983 / 84$ & - & - \\
$1984 / 85$ & 45.65 & $11 / 2 / 1985$ \\
$1985 / 86$ & 43.89 & $23 / 3 / 1986$ \\
$1986 / 87$ & 46.65 & $10 / 5 / 1987$ \\
$1987 / 88$ & 38.28 & $10 / 5 / 1988$ \\
$1988 / 89$ & 44.70 & $06 / 5 / 1989$ \\
$1989 / 90$ & 49.48 & $30 / 4 / 1990$ \\
$1990 / 91$ & 44.52 & $20 / 4 / 1991$ \\
$1991 / 92$ & 49.24 & $23 / 41992$ \\
$1992 / 93$ & 41.07 & $04 / 4 / 1993$ \\
$1993 / 94$ & 47.02 & $14 / 5 / 1994$ \\
$1994 / 95$ & 43.42 & $11 / 5 / 1995$ \\
$1995 / 96$ & 36.92 & $03 / 5 / 1996$ \\
$1996 / 97$ & 25.25 & $24 / 4 / 1997$ \\
$1997 / 98$ & - & - \\
$1998 / 99$ & 46.91 & $17 / 4 / 1999$ \\
$1999 / 00$ & 59.23 & $08 / 6 / 2000$ \\
\hline
\end{tabular}

An empirical method of determining the climateagriculture relationship was adopted, using agricultural and climatic data for a period limited by the duration of a consistent record. Olaniran \& Babatolu (1987) have suggested the use of phenological stages as time intervals (rather than using the whole year) for processing data on the influence of climatic variables on agricultural production, thereby detecting the critical physiological stages for yield formation. On this basis, the data collected were processed using the growth cycle of sugar cane as identified by the Agronomy Division of the Savanna Sugar Company. Duration of each stage was established through personal communications with research fellows at the SSCL. The stages are as follows:

(1) Germination stage (3 wk or $21 \mathrm{~d}$ )

(2) Establishment stage (2 mo or $60 \mathrm{~d}$ )

(3) Boom (grand growth) stage (4 mo or $120 \mathrm{~d}$ )

(4) Sucrose build up (maturity) stage (5 mo or $150 \mathrm{~d}$ )

The nature and extent of the relationship between sugar cane yield and climatic variables at each stage of growth was examined using correlation analysis, while stepwise multiple regression analysis was employed to determine the combined effect of the climatic elements on sugar cane yield. The correlation coefficients were tested at 1,5 and $10 \%$ significance levels. The $10 \%$ level is allowed because of the short duration of the data period.

\section{RESULTS AND DISCUSSION}

\subsection{Correlations between climate and yield}

The result of the simple correlation between the elements of climate and sugar cane yield in SSCL, is presented in Table 2. The results show differences in the effect of each element on sugar cane yield at different stages of growth. Climate-yield correlations for each phenological stage are discussed below.

\subsection{Germination stage}

The germination stage is the period between planting and germination, which on average lasts $21 \mathrm{~d}$. The results in Table 2 show that out of the 7 meteorological variables, only total rainfall, mean relative humidity, Tmin and mean evaporation are correlated significantly with yield. Total rainfall exhibited a negative relationship at $90 \%$ confidence level. This implies that too much rainfall at the time of planting is detrimental for the sugar cane setts (canes that have been cut into 2 or 3 nodes and planted). Too much rain after sett 
Table 2. Climate-Sugar cane yield correlations at Savanna Sugar Company, Numan. RH: relative humidity; evap.: evaporation; vel.: velocity. ${ }^{*} \mathrm{p} \leq 0.1,{ }^{* *} \mathrm{p} \leq 0.05,{ }^{* * *} \mathrm{p} \leq 0.01$

\begin{tabular}{|lccccccc|}
\hline Variable & $\begin{array}{c}\text { Rainfall } \\
(\mathrm{mm})\end{array}$ & $\begin{array}{c}\text { Mean RH } \\
(\%)\end{array}$ & $\begin{array}{c}\text { Tmax } \\
\left({ }^{\circ} \mathrm{C}\right)\end{array}$ & $\begin{array}{c}\text { Tmin. } \\
\left({ }^{\circ} \mathrm{C}\right)\end{array}$ & Mean evap. & $\begin{array}{c}\text { Mean wind vel. } \\
\left(\mathrm{km} \mathrm{h}^{-1}\right)\end{array}$ & $\begin{array}{c}\text { Sunshine } \\
(\mathrm{h})\end{array}$ \\
\hline Germination & $-0.458^{*}$ & $-0.491^{* *}$ & -0.294 & $-0.427^{*}$ & $0.762^{* * *}$ & 0.078 & 0.353 \\
Establishment & $-0.630^{* *}$ & 0.366 & 0.176 & 0.148 & $0.792^{* * *}$ & $0.411^{*}$ & 0.246 \\
Boom & 0.098 & 0.169 & 0.087 & -0.312 & $0.773^{* * *}$ & 0.1 & 0.267 \\
Maturity & 0.097 & 0.282 & 0.008 & 0.042 & 0.396 & 0.221 & 0.168 \\
Total growing season & -0.295 & $-0.452^{*}$ & -0.145 & $-0.452^{*}$ & $0.784^{* * *}$ & 0.247 \\
\hline
\end{tabular}

planting may result in waterlogging, which causes cane rot. This finding supports the earlier work of Jika (1997) who stated that the best period for planting commercial sugar cane for the mills (SSCL) is between November and April, which are dry months in the study area.

Tmin also showed a negative correlation at the $90 \%$ confidence level. This implies that very cold periods are not conducive to germination. This fact is further supported by Humbert (1963) who reported that temperature effects are particularly noticeable in germination studies. Optimum germination temperature is $\sim 32$ to $38^{\circ} \mathrm{C}$. Whenever temperatures drop below $21^{\circ} \mathrm{C}$, germination is either very slow or fails. Earlier investigators learned that hot water treatment of seed results in increased germination when seeds are planted in cool soils (Humbert 1963).

Mean relative humidity also exhibits a strong negative correlation with germination at the $5 \%$ confidence level. This is not surprising since relative humidity is strongly correlated with total rainfall, which has negative effect on germination.

Mean pan evaporation at germination stage shows a strong positive correlation at the $1 \%$ confidence level. This finding agrees with the work of Clements \& Kubota (1942) who explained the necessity of high evaporation at germination. This is relevant because transpiration of large quantities of moisture is necessary in order to enable the sugar cane plant to safely project itself into a high-energy environment of sunlight and air temperatures, which provides rapid photosynthesis and growth.

\subsection{Establishment stage}

The second stage in the growth cycle of sugar cane is known as the establishment stage. It is characterized by node development and leaf formation. This period lasts between 2 and 3 mo. Correlation with mean values of the climatic variables at this stage shows that total rainfall has a strong negative relationship at the $5 \%$ confidence level. This implies that too much rain at this stage is not good for the young sugar cane plant.
At this stage in the study area, the rains are fully established. Therefore controlled irrigation is withdrawn (M. Jika, pers. comm.). The distribution of rainfall is of great importance since excess rainfall is not only ineffective, but may cause reduced rate of growth where drainage is impeded (Humbert 1963).

Mean evaporation exhibits a strong positive relationship with sugar cane yield. This is not surprising because, according to Clements \& Kubota (1942), the internal moisture relation in sugar cane is a dominant factor in the synthesis and translocation of sugars. High evaporation at this stage is favorable for the sucrose build-up process.

Mean wind velocity shows positive and significant correlation at the $10 \%$ confidence level. This is because tissue moisture levels are determined by factors such as wind velocity, sunshine and evaporation which are effective in either increasing water absorption or in increasing transpiration (Clements 1995). In addition, the exposure of the sugar cane plant to wind at this stage tends to increase the root development for effective adsorption, as compare to that of sheltered plants (Lakshmikanthan 1983). It also affects the rate of evapotranspiration, which positively influences sugar cane establishment.

\section{4. 'Boom' stage}

The Boom stage is the phase of maximum development in the sugar cane plant and is characterized by increases in stem size, weight and high leaf production. This stage typically commences 4 mo after planting and lasts until the 7 th month, a total period of about 120 d. Only mean evaporation has a significant positive correlation with sugar cane yield at this stage. This corroborated the findings of Blackie \& Bjorking (1968) who reported that sugar cane at this stage (after $4 \mathrm{mo}$ ) tends to have a very high rate of evapotranspiration, the implication being that high evaporative demand on sugar cane causes it to expel excess water through evapotranspiration, thus allowing some of the sugar produced to be used for building new tissue. In Tanzania, Blackie \& Bjorking (1968) found that evapo- 
transpiration existed throughout the life cycle of sugar cane, being highest during the establishment and boom.

\subsection{Maturity stage}

The 4th and last identified stage in the growth cycle of sugar cane is known as the maturity phase or sucrose build-up stage. This phase, characterized by a retardation in the rate of growth, commences 8 mo after planting and runs through to the 12th month (harvest time) spanning a period of about $150 \mathrm{~d}$. All climatic variables correlate positively with growth and yield, but none are significant.

\subsection{Total growing season}

The results in Table 2 show that out of the 7 climatic variables used in this study, relative humidity, Tmin and mean evaporation have significant effects on the growth and yield of sugar cane in SSCL. Relative humidity and Tmin exhibit negative correlations, while pan evaporation shows a positive relationship. The implication on sugar cane yield of these correlations has been discussed in Section 3.2 \& 3.4.

\subsection{Combined effect of climatic elements on growth and yield}

The combined effects of the different climatic elements on the yield of sugar cane in Numan were also investigated using stepwise regression techniques. We included only those climatic variables which correlated significantly with yield during the 4 stages of growth, i.e. mean relative humidity at germination stage, total rainfall at establishment stage, mean evaporation at germination, establishment at boom stage, total rainfall at germination stage, Tmin at germination stage and wind velocity at establishment stage. Out of the 8 elements, 2 variables (pan evaporation at boom stage and Tmin at germination stage) fit the regression model (Table 3), showing that they contributed significantly to the variation in yield of sugar cane in

Table 3. Stepwise regression of climatic elements on sugar cane yield

\begin{tabular}{|lcccc|}
\hline Variable & Partial $\mathrm{R}^{2}$ & Model $\mathrm{R}^{2}$ & $F$ & $\mathrm{p}$ \\
\hline Evaporation & 59.8 & 59.8 & 23.79 & 0.00 \\
Tmin & 9.4 & 68.2 & 16.06 & 0.00 \\
\hline
\end{tabular}

SSCL. The 2 variables together accounted for $>68 \%$ of the total variance in the yield of cane in Numan. While evaporation relates positively to yield, Tmin on the other hand exhibits a negative relationship with yield. Evaporation at boom stage explains $59.8 \%$ of yield variation, while minimum temperature at germination accounts for $9.4 \%$. The importance of these 2 elements on the growth and yield of sugar cane has been discussed in Sections 3.2 \& 3.4 .

\subsection{Implication for sugar cane farming}

The results of the correlation and regression analysis between sugar cane yield and climatic elements presented and discussed above (Sections 3.1-3.8) have shown that climate plays an important role in agricultural productivity in the region. Climate mechanisms that are important to the region include El Niño, where over the years the Nigerian region has seen reduced rainfall, and higher temperatures and evaporation. Furthermore, observed and predicted climate change has the potential to greatly impact sugar cane production in the region. For example, this research shows that evaporation alone accounts for $59.8 \%$ of the yield variation in the study area. Projections of the effects of regional climate change tend towards lower crop yields in the study area, and this is already evident in the yield of sugar cane (except for the last $2 \mathrm{yr}$ of the study period when noticeable increases were observed). In order to optimize technological applications and advances in methods of crop husbandry on crop production, the beneficial effects of climate on the crop yield must be optimized while the negative influence must be minimized if not completely avoided. Thus for Numan, the present planting period of between February and May should be maintained, since the influence of the Harmattan winds is mostly felt between November and January, when temperatures fall to a critical stage whereby germination is either slowed down or stopped completely. However, Tmin between February and May allows for high water and nutrient absorption, and planting in this period also avoids the damaging effects of squally winds (associated with onsets of rains in this part of the country) on the sugar cane plant, which is relatively weak and brittle at establishment stage (Binbol 2005).

Rainfall amounts that are more than adequate for agriculture in the temperate latitudes can be insufficient in the tropics because of the high evaporative demand of the atmosphere and therefore crop water requirements (Jackson 1993). This is quite true for sugar cane, which exhibits high evapotranspiration throughout its development stages. The implication of this in 
the tropics is that it expels excess cane water, which has been absorbed through irrigation assistance, and leaves a high concentration of sucrose, thereby increasing the sugar content per unit of output.

\section{CONCLUSION}

Evaporation at boom stage and Tmin at germination stage are the critical climatic factors affecting the variations in crop yield. This preliminarly work on climate-sugar cane yield relationships is not exhaustive. Further studies will be required to establish the effect of early and late harvest on sugar cane productivity. There is also the need, especially in Nigeria, to introduce the use of platform sensors for monitoring sugar cane conditions, which will in turn improve yield forecasting.

\section{LITERATURE CITED}

Adebayo AA (1999) Climate II. In: Adebayo AA, Tukur AL (eds) Adamawa State in Maps. Paraclete publishers, Yola

Binbol NL (2005) Season variation in line squall and thunderstorm activities in Yola. J Nat Appl Sci 1(1):59-65

Blackie F, Bjorkings L (1968) Lysimeter study of the water use

Guest Editor: Gregory Jones,

Ashland, Oregon, USA of sugar cane. Proceeding of the specialist Meeting on Applied Meteorology in East Africa, Nairobi

Clements HF (1995) Sugar cane crop logging and crop control: principles and practices. University of Hawaii Press, Honolulu, HI

Clements HF, Kubota T (1942) Internal moisture relations of sugar cane, the selection of moisture index. Hawaii Plant Rec 46:17-35

Ericksen S (2005) Linkages between climate change and desertification in East Africa. Part 1. Physical and social linkages. Available online at cals.arizona.edu/OALS/ALN/ aln49/eriksen-part1.html

Humbert RP (1963) The growing of sugar cane. Elsevier, New York

Jackson IJ (1993) Climate, water and agriculture in the tropics. Longman, London

Jika M (1997) Improved sugar cane production practices at Savannah Sugar Company Limited SSCL. Presented at Monthly Technical Report Meeting (MTRM), Adamawa Agricultural Development Project AADP, Yola

Kochhar SL (1986) Tropical crops: a textbook of economic botany. Macmillan, London

Laskhmikantham M (1983) Technology in sugar cane growing. Oxford \& IBH, New Delhi

Mirchaulum PT, Eguda Y (1995) Manufacturing industries in Adamawa state: Savannah Sugar Company Numan. Occasional Paper 3, Federal University of Technology, Yola

Olaniran OJ, Babatolu JS (1987) Climate and the growth of sorghum at Kabba, Nigeria. J Agric Metereol 42:301-308

Purseglove JW (1985) Tropical crops: monocotyledons. Vol. I and II. Longman, Singapore

Submitted: December 14, 2005; Accepted: July 19, 2006

Proofs received from author(s): August 29, 2006 